Received: 23 May 2018

Accepted: 29 January 2019

Published online: 06 March 2019

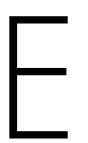

C N

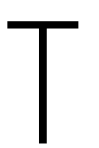

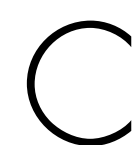

RE

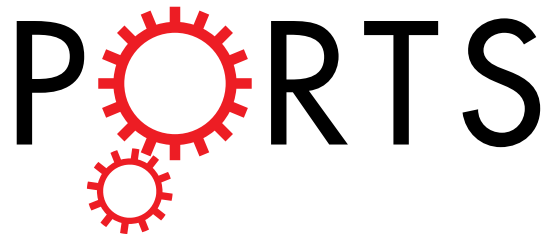

\title{
OPEN
}

\section{The different influences of drought stress at the flowering stage on rice physiological traits, grain yield, and quality}

\author{
Xiaolong Yang ${ }^{1}$, Benfu Wang ${ }^{1}$, Liang Chen ${ }^{1}$, Ping $\mathrm{Li}^{1,2}$ \& Cougui Cao ${ }^{1,2}$
}

Seasonal drought is a major threat to rice production. However, the sensitivity of rice to drought stress (DS) at different growth periods remains unclear. The objective of this study was to reveal the different impacts of $D S$ at the flowering stage on rice physiological traits, grain yield, and quality. Field experiments were conducted with two rice cultivars, Yangliangyou 6 (YLY6) and Hanyou 113 (HY113) under two water treatments (traditional flooding (CK) and DS at flowering stage) in 2013 and 2014. Compared with CK, grain yield (GY) under DS was significantly reduced by $23.2 \%$ for YLY6 and $24.0 \%$ for HY113 while instantaneous water use efficiency (IWUE) was significantly increased by $39 \%$ for YLY 6 and $37 \%$ for $\mathrm{HY} 113$, respectively. All physiological traits were significantly decreased under DS and physiological activities did not revert to normal levels at grain filling stage. There was no significant effect on the appearance and nutritional quality except for the significant increase in chalky kernel and chalkiness under DS. Our data suggest that drought stress at flowering stage has a strong influence on rice physiological traits and yield. Stronger recovery capability contributes to maintaining relatively high grain production, which could be a great target for the breeder in developing drought-tolerant rice cultivars.

Rice (Oryza sativa L.) is a staple food for nearly half of the world,s population, and its production is urgent needed with the rapidly increase of population in coming decades, especially in Asia countries ${ }^{1,2}$. Rice consumes almost $80 \%$ of the total irrigation freshwater resources ${ }^{3,4}$. However, with urbanization and industrialization, fresh water is becoming rare, DS may be a great challenge to agricultural production all over the world ${ }^{5}$. According to statistics, approximately 42 million hectares of rice is subject to occasional or frequent DS in Asia, resulting in significant yield $\operatorname{loss}^{6}$. Thus, it is important to provide more staple rice to keep global food security and to meet the food needs of a growing world population ${ }^{7}$. As the major rice production region, South China produces more than $80 \%$ of cereal food of the country ${ }^{8}$. Although abundant rainfall is supplied in South China, water shortage is still exist because of the uneven distribution of among seasons and regions ${ }^{9}$. Therefore, it is important to save water and increase the crop water use efficiency (WUE) in arid, semi-arid areas and seasonal drought regions ${ }^{4,10}$.

Rice is highly susceptible to water stress during the reproductive stage, leading to significant reduction in grain $\mathrm{GY}^{11,12}$. The yield loss magnitude depends on the growth stage and duration, the severity of $\mathrm{DS}^{13,14}$. Severe DS applied at the vegetative stage and mild DS applied at the flowering stage in rice in one trial result in $20 \%$ and $28 \%$ yield loss, respectively ${ }^{15}$. However, the field experiment of major rice varieties remains unclear in Hubei Province, China. Besides the yield of rice, grain quality is an important indicator for farmers, the milling, appearance and nutrient characters of grain were determined both environmentally and genetically ${ }^{16,17}$. Grain quality of rice including the percentages of brown rice rate (BRR), milled rice rate (MRR), head rice rate (HRR) in total rice grains, chalky kernel (CHK) and chalkiness $(\mathrm{CH})$, the grain shape $(\mathrm{GS})$ of length and width, protein content, amylose content and alkali spreading value is very important in agriculture ${ }^{17-19}$. All quality parameters were measured according to Rice Quality Measurement Standards (Ministry of Agriculture PR China, 1988) ${ }^{16,20}$. Generally, BRR, HRR, and MRR in total rice grains, $\mathrm{CH}$ and $\mathrm{CHK}$ have negative effects on grain quality. Thus,

${ }^{1}$ College of Plant Science and Technology, Huazhong Agricultural University, Wuhan, Hubei, 430070, China. ${ }^{2}$ Hubei Collaborative Innovation Center for Grain Industry, Yangtze University, Jingzhou, Hubei, 434025, China. Correspondence and requests for materials should be addressed to P.L. (email: sleep1022@mail.hzau.edu.cn) or C.C. (email: ccgui@mail.hzau.edu.cn) 


\begin{tabular}{|l|l|l|l|l|l|l|}
\hline Year & Month & $\begin{array}{l}\text { Average } \\
\text { temperature }\left({ }^{\circ} \mathbf{C}\right)\end{array}$ & $\begin{array}{l}\text { Maximum } \\
\text { temperature }\left({ }^{\circ} \mathbf{C}\right)\end{array}$ & $\begin{array}{l}\text { Minimum } \\
\text { temperature }\left({ }^{\circ} \mathbf{C}\right)\end{array}$ & $\begin{array}{l}\text { Precipitation } \\
(\mathbf{m m} \text { per month) }\end{array}$ & $\begin{array}{l}\text { Sunshine (h } \\
\text { per month) }\end{array}$ \\
\hline \multirow{5}{*}{2013} & May & 23.0 & 34.0 & 15.0 & 206 & 146 \\
\cline { 2 - 7 } & Jun & 26.3 & 38.1 & 18.3 & 205 & 207 \\
\cline { 2 - 7 } & Jul & 30.6 & 38.0 & 23.6 & 479 & 280 \\
\cline { 2 - 7 } & Aug & 31.1 & 40.4 & 23.9 & 25.3 & 233 \\
\cline { 2 - 7 } & Sep & 23.7 & 34.1 & 14.3 & 201 & 149 \\
\cline { 2 - 7 } & Oct & 20.2 & 31.8 & 9.8 & 3.80 & 235 \\
\hline \multirow{3}{*}{ Mean } & & 25.8 & 36.1 & 17.5 & 187 & 208 \\
\hline \multirow{5}{*}{2014} & May & 22.1 & 32.1 & 13.8 & 163 & 157 \\
\cline { 2 - 7 } & Jun & 26.0 & 33.8 & 21.9 & 46 & 113 \\
\cline { 2 - 7 } & Jul & 27.6 & 37.6 & 20.8 & 134 & 181 \\
\cline { 2 - 7 } & Aug & 26.2 & 37.0 & 20.5 & 115 & 115 \\
\cline { 2 - 7 } & Sep & 24.5 & 33.8 & 17.8 & 64 & 133 \\
\cline { 2 - 7 } & Oct & 20.3 & 30.4 & 13.1 & 144 & 206 \\
\hline Mean & 24.4 & 34.1 & 18.0 & 111 & 151 \\
\hline
\end{tabular}

Table 1. Mean temperature, maximum temperature, minimum temperature, sunshine and precipitation per month during the whole growing season of rice across two years (2013-2014) in Wuhan, China.

protein content, amylose content might have positive effects ${ }^{21,22}$. Flowering stage is critical for rice yield and quality formation. Thus, it is significant to study different influences of DS at the flowering stage on rice physiological traits, GY, and quality and to reveal the influence mechanism. Although some studies have studied GY and quality under different cultivation conditions and cultivars ${ }^{1,2,17}$, the mechanisms of crops respond to DS at flowering stage remains largely unknown, affecting the improvement of drought-tolerant crops $^{23}$.

In addition, improvement of WUE for securing the environmental sustainability of rice production in southern seasonal drought areas, since rice production relies on the use of large volumes of fresh water ${ }^{24}$. Generally, WUE is determined by the ratio of GY to total water consumption (rainfall and irrigation) during the whole growth period ${ }^{17,25}$, by the ratio of photosynthetic rate $\left(\mathrm{P}_{n}\right)$ to transpiration rate $\left(\mathrm{T}_{\mathrm{r}}\right)^{26}$. Moreover, carbon isotope discrimination $(\Delta)$ as an indirect mean to explain WUE is widely used in wheat ${ }^{27}$, rice, and there may be negative relationship between WUE and $\Delta^{22,28,29}$. Thus, WUE is important to crop yield under $\mathrm{DS}^{30,31}$, and it can be calculated with the ratio of yield to irrigation ${ }^{17}, \mathrm{P}_{\mathrm{n}}$ to $\mathrm{T}_{\mathrm{r}}{ }^{26}$ and $\Delta^{32}$.

Rice GY is closely related to photosynthesis of the functional leaves, solar energy and atmospheric carbon dioxide $\left(\mathrm{CO}_{2}\right)$ captured by crops through photosynthesis is the main component of yield ${ }^{33-35}$. Therefore, it is necessary to understand the mechanisms of leaf gas exchange, photosynthesis and other related physiological traits to $\mathrm{DS}^{36}$. Rice production is limited by water availability and the low leaf-level photosynthetic capacity of many cultivars $^{20}$. Generally, the decrease of stomatal conductance $\left(G_{s}\right)$ in leaves is accompanied with reducing transpiration rate, resulting in the loss of photosynthesis and lower production in biomass ${ }^{17,37}$. As an important indicator of drought resistance in rice, higher leaf water potential (LWP) is considered as the anti-dehydration mechanism, and the decrease of leaf-level $P_{n}$ is always accompanied with LWP decrease and relative water content ${ }^{38,39}$. In addition, a long-term soil water deficit may change the rice canopy microclimate, but an intense physiological activity under a lower organ temperature was observed, indicating that a relatively lower canopy temperature or organ temperature could enhance resistance to heat and stress injury ${ }^{40}$. Actually, the transpiration rate could decrease under water deficit, leading to the decrease of energy consumption for transpiration and the air-leaf temperature difference $^{41}$. In the last two decades, more frequent seasonal drought struck southern of China, causing water crisis for residents and damaged millions of hectares croplands ${ }^{42,43}$. Reduction in rice GY by DS occurs during reproductive development, especially at the flowering stage, and mild DS may result in severe GY loss ${ }^{6,44}$. The objectives of our study were to reveal the impact of DS at the flowering stage on rice yield and quality performance and to elucidate the physiological response to drought underlying the changes of yield and quality. The $P_{n}, G_{s}, T_{r}$, instantaneous WUE (IWUE), $\Delta$, LWP, air-leaf temperature gap (ALTG), GY and grain quality were determined in this study. To better understand the mechanism of change in spikelets sterility, this study focused on the physiological changes of the flag leaves of rice, particular in LWP and ALTG under DS at the flowering stage.

\section{Results}

Analysis of variance. In this study, field experiments were conducted with YLY6 and HY113 in 2013 and 2014 in Wuhan, and the detailed information of whole growing season was shown in Table 1. Generaly, the maximum temperature, minimum temperature, and average temperature showed no difference between 2013 and 2014 , the sunshine and precipitation were significantly higher in 2013 than in 2014 . Variation in the precipitation across months was greater in 2013 than in 2014, and low precipitation was observed in August 2013 and in June 2014. Analysis of variance (F-values) for GY, grain components and some physiological traits of rice among years, varieties and treatments were shown in Table 2. Significant differences $(P<0.05)$ were occurred for most evaluated traits between the two varieties and among treatments.

GY, yield components, and grain quality. DS at flowering stage significantly reduced GY for both YLY6 and HY113. No significant difference in GY occurred between two rice genotypes (Table 3). Yield components of 


\begin{tabular}{|l|l|l|l|l|l|l|l|l|l|l|l|l|}
\hline Source of variation & df & GY & SPN & FG & CH & LWP & ALTG & $\mathbf{P}_{\mathrm{n}}$ & $\mathbf{G}_{\mathrm{s}}$ & $\mathbf{T}_{\mathbf{r}}$ & IWUE & $\boldsymbol{\Delta}$ \\
\hline Year (Y) & 1 & $0.08 \mathrm{~ns}$ & $0.05 \mathrm{~ns}$ & $0.02 \mathrm{~ns}$ & $20.5^{* *}$ & $748^{* *}$ & $12.6^{* *}$ & $1.52 \mathrm{~ns}$ & $4.20 \mathrm{~ns}$ & $8.38^{*}$ & $2.19 \mathrm{~ns}$ & $5.01^{*}$ \\
\hline Varieties (V) & 1 & $3.33 \mathrm{~ns}$ & $12.2^{* *}$ & $5.81^{*}$ & $248^{* *}$ & $227^{* *}$ & $68.5^{* *}$ & $1.56 \mathrm{~ns}$ & $1.09 \mathrm{~ns}$ & $63.0^{* *}$ & $28.5^{* *}$ & $100^{* *}$ \\
\hline Treatment (T) & 1 & $352^{* *}$ & $137^{* *}$ & $159^{* *}$ & $230^{* *}$ & $469^{* *}$ & $574^{* *}$ & $142^{* *}$ & $176^{* *}$ & $509^{* *}$ & $119^{* *}$ & $1.13 \mathrm{~ns}$ \\
\hline $\mathrm{Y} \times \mathrm{V}$ & 1 & $19.9 * *$ & $0.79 \mathrm{~ns}$ & $3.40 \mathrm{~ns}$ & $9.21 \mathrm{~ns}$ & $319^{* *}$ & $83.5^{* *}$ & $2.01 \mathrm{~ns}$ & $0.37 \mathrm{~ns}$ & $22.7^{* *}$ & $3.82 \mathrm{~ns}$ & $1.68 \mathrm{~ns}$ \\
\hline $\mathrm{Y} \times \mathrm{T}$ & 1 & $15.5^{* *}$ & $0.15 \mathrm{~ns}$ & $10.6^{* *}$ & $14.9^{* *}$ & $80.5^{* *}$ & $75.8^{* *}$ & $0.16 \mathrm{~ns}$ & $1.26 \mathrm{~ns}$ & $0.08 \mathrm{~ns}$ & $2.42 \mathrm{~ns}$ & $19.0^{* *}$ \\
\hline $\mathrm{V} \times \mathrm{T}$ & 1 & $1.95 \mathrm{~ns}$ & $1.66 \mathrm{~ns}$ & $0.50 \mathrm{~ns}$ & $52.0^{* *}$ & $9.83^{* *}$ & $45.8^{* *}$ & $0.37 \mathrm{~ns}$ & $4.52 \mathrm{~ns}$ & $3.47 \mathrm{~ns}$ & $0.29 \mathrm{~ns}$ & $3.13 \mathrm{~ns}$ \\
\hline
\end{tabular}

Table 2. Analysis of variance (F-values) for GY, grain components and some physiological traits of rice among years, varieties and treatments. Grain yield, GY; Spikelets per panicle, SPN; Filled grains, FG; Chalkiness, CH; Leaf water potential, LWP; Air-leave temperature gap, ALTG; Net photosynthetic, $\mathrm{P}_{\mathrm{n}}$; Stomatal conductance, $\mathrm{G}_{\mathrm{s}}$; Instantaneous water use efficiency, IWUE; Carbon isotope discrimination, $\Delta$. *Significant at the 0.05 probability level. **Significant at the 0.01 probability level.

\begin{tabular}{|l|l|l|l|l|l|l|l|}
\hline Year & Varieties & Treatment & SPN & EP $\left(\times \mathbf{1 0}^{\mathbf{3}} \mathbf{m}^{-\mathbf{2}}\right)$ & $\mathbf{F G}(\mathbf{\%})$ & TGW $(\mathbf{g})$ & GY $\left(\mathbf{t} . \mathbf{h}^{-\mathbf{1}}\right)$ \\
\hline & YLY6 & CK & $164 \mathrm{a}$ & $43.5 \mathrm{a}$ & $75.5 \mathrm{a}$ & $26.2 \mathrm{a}$ & $10.45 \mathrm{a}$ \\
\hline 2013 & & DS & $139 \mathrm{~b}$ & $34.5 \mathrm{~b}$ & $61.2 \mathrm{~b}$ & $25.7 \mathrm{a}$ & $8.03 \mathrm{~b}$ \\
\hline & HY113 & CK & $180 \mathrm{a}$ & $43.3 \mathrm{a}$ & $85.3 \mathrm{a}$ & $27.1 \mathrm{a}$ & $10.65 \mathrm{a}$ \\
\hline & & DS & $144 \mathrm{~b}$ & $35.1 \mathrm{~b}$ & $67.4 \mathrm{~b}$ & $26.8 \mathrm{a}$ & $8.09 \mathrm{~b}$ \\
\hline & Mean & & 156 & 39.1 & 72.4 & 26.5 & 9.31 \\
\hline & YLY6 & CK & $166 \mathrm{a}$ & $40.9 \mathrm{a}$ & $77.8 \mathrm{a}$ & $26.3 \mathrm{a}$ & $10.35 \mathrm{a}$ \\
\hline & & DS & $131 \mathrm{~b}$ & $29.4 \mathrm{~b}$ & $63.4 \mathrm{~b}$ & $25.8 \mathrm{a}$ & $9.12 \mathrm{~b}$ \\
\hline & HY113 & CK & $178 \mathrm{a}$ & $43.4 \mathrm{a}$ & $74.8 \mathrm{a}$ & $27.1 \mathrm{a}$ & $10.06 \mathrm{a}$ \\
\hline & & DS & $139 \mathrm{~b}$ & $32.9 \mathrm{~b}$ & $61.7 \mathrm{~b}$ & $27.2 \mathrm{a}$ & $8.39 \mathrm{~b}$ \\
\hline
\end{tabular}

Table 3. GY and yield components of two rice cultivars of YLY6 and HY113 under DS at flowering stage in 2013 and 2014. Different letters indicate statistical significance according to LSD $(P=0.05)$. TGW and GY are expressed at $14 \%$ moisture content.

\begin{tabular}{|l|l|l|l|l|l|l|l|l|}
\hline Year & Varieties & Treatment & BRR (\%) & MRR (\%) & HRR (\%) & CHK (\%) & CH (\%) & GS (\%) \\
\hline & YLY6 & CK & $79.4 \mathrm{a}$ & $69.3 \mathrm{a}$ & $59.9 \mathrm{a}$ & $15.1 \mathrm{~d}$ & $4.10 \mathrm{c}$ & $2.90 \mathrm{a}$ \\
\hline 2013 & & DS & $79.9 \mathrm{a}$ & $69.9 \mathrm{a}$ & $62.6 \mathrm{a}$ & $25.5 \mathrm{c}$ & $8.40 \mathrm{~b}$ & $2.90 \mathrm{a}$ \\
\hline & HY113 & CK & $77.7 \mathrm{a}$ & $66.6 \mathrm{a}$ & $53.4 \mathrm{~b}$ & $37.0 \mathrm{~b}$ & $9.00 \mathrm{~b}$ & $2.90 \mathrm{a}$ \\
\hline & & DS & $77.8 \mathrm{a}$ & $66.0 \mathrm{a}$ & $50.2 \mathrm{~b}$ & $58.9 \mathrm{a}$ & $15.6 \mathrm{a}$ & $2.90 \mathrm{a}$ \\
\hline & YLY6 & CK & $82.1 \mathrm{a}$ & $71.7 \mathrm{a}$ & $67.6 \mathrm{a}$ & $15.1 \mathrm{~d}$ & $5.63 \mathrm{c}$ & $2.83 \mathrm{~b}$ \\
\hline 2014 & & DS & $81.1 \mathrm{a}$ & $70.9 \mathrm{a}$ & $67.3 \mathrm{a}$ & $24.9 \mathrm{c}$ & $8.07 \mathrm{ab}$ & $2.77 \mathrm{~b}$ \\
\hline & HY113 & CK & $81.4 \mathrm{a}$ & $71.0 \mathrm{a}$ & $59.8 \mathrm{~b}$ & $30.0 \mathrm{~b}$ & $7.97 \mathrm{ab}$ & $3.00 \mathrm{a}$ \\
\hline & & DS & $80.8 \mathrm{a}$ & $70.3 \mathrm{a}$ & $59.1 \mathrm{~b}$ & $44.0 \mathrm{a}$ & $14.2 \mathrm{a}$ & $3.00 \mathrm{a}$ \\
\hline
\end{tabular}

Table 4. Milling and appearance quality of two rice cultivars of YLY6 and HY113 under DS during flowering stage in 2013 and 2014. Different letters indicate statistical significance according to $\operatorname{LSD}(P=0.05)$.

the number of spikelets per panicle (SPN) and filled grains (FG) were significantly reduced by $18 \%$, and $19 \%$ for YLY6 and 21\%, and 19\% for HY113, respectively, when compared with the traditional flooding irrigation system on average across two seasons, which contribute to the significantly decreased in GY in YLY6 and HY113 and reduced by $23.2 \%, 24.0 \%$ respectively under DS. In addition, DS at flowering stage had no significant effect on the effective panicle (EP) and 1000-grain weight (TGW).

No significant differences existed in BRR, MRR, HRR and GS for YLY6 and HY113, and DS at the flowering cause no significant change for these traits either (Table 4). Compared with CK, CHK and CH under DS were significantly increased by 67\%, 74\% in YLY6 and 53\%, 76\% in HY113 on average across two seasons, respectively. When the comparison was made between YLY6 and HY113 under the same water management, the head rice rate of YLY6 was 13\% higher than that of HY113 under CK and 20\% higher under DS; and CHK and CH degree of HY113 were higher than YLY6, CHK of HY113 was 122\% higher under CK, 99.2\% higher under DS than that of YLY6, respectively, CH of HY113 was $81 \%$ higher under CK, 82\% higher under DS than that of YLY6, respectively.

Under CK and DS conditions, the protein content, amylose content and alkali spreading value of every variety showed no significant difference. However, the two rice varieties displayed significant difference in protein 


\begin{tabular}{|l|l|l|l|l|l|}
\hline Year & Varieties & Treatment & Protein content (\%) & Amylose content (\%) & Alkali spreading value \\
\hline & YLY6 & CK & $11.0 \mathrm{a}$ & $16.9 \mathrm{a}$ & $7.23 \mathrm{a}$ \\
\hline 2013 & & DS & $11.1 \mathrm{a}$ & $17.1 \mathrm{a}$ & $7.30 \mathrm{a}$ \\
\hline & HY113 & CK & $8.77 \mathrm{~b}$ & $16.8 \mathrm{a}$ & $7.17 \mathrm{a}$ \\
\hline & & DS & $8.70 \mathrm{~b}$ & $17.1 \mathrm{a}$ & $7.17 \mathrm{a}$ \\
\hline & YLY6 & CK & $10.5 \mathrm{a}$ & $17.1 \mathrm{a}$ & $7.13 \mathrm{a}$ \\
\hline 2014 & & DS & $10.7 \mathrm{a}$ & $17.1 \mathrm{a}$ & $7.20 \mathrm{a}$ \\
\hline & HY113 & CK & $8.40 \mathrm{~b}$ & $16.7 \mathrm{a}$ & $7.13 \mathrm{a}$ \\
\hline & & DS & $8.47 \mathrm{~b}$ & $16.7 \mathrm{a}$ & $7.00 \mathrm{a}$ \\
\hline
\end{tabular}

Table 5. Nutritional quality of two rice cultivars of YLY6 and HY113 under DS at flowering stage in 2013 and 2014. Different letters indicate statistical significance according to LSD $(P=0.05)$.

content under both CK and DS conditions. Generally, YLY6 showed 25\% and 27\% higher protein content than HY113 under CK and DS conditions, respectively (Table 5).

The physiological change in response to DS. The physiological traits including $P_{n}, G_{s}$, and $T_{r}$ of leaves were significantly decreased under DS during the flowering stage (Fig. 1). The $P_{n}, G_{s}$, and $T_{r}$ of leaves reduced by $24 \%, 41 \%, 30 \%$ on average across two seasons respectively. The $P_{n}, G_{s}$ of leaves showed no significant difference between YLY6 and HY113 under the same water treatment across two seasons (Fig. 1). $T_{\mathrm{r}}$ of YLY6 was slightly higher than that of HY113 under both water treatments, with no statistical difference.

Generally, LWP of two cultivars (YLY6, HY113) showed lower level under DS than CK in 2013 and 2014, except for HY113 in 2013 (Fig. 2). To better understand the leaf temperature responses to DS, we calculated the temperature gap between air and leaves. As shown in Fig. 3, the DS significantly decreased the ALTG when compared with CK under the similar temperature and relative humidity. The ALTG was reduced by $51 \%$ in YLY6 and 39\% in HY113 on average across two seasons respectively. There was no significant difference between two cultivars YLY6 and HY113 under CK, while there was a significant increase in ALTG in HY113 compared with YLY6 under DS, the difference was 16\% and 32\% in 2013 and 2014, respectively.

IWUE and $\Delta$. Compared with that under the traditional flooding cultivation, the IWUE of these two cultivars was remarkably increased under DS conditions, with 39\% for YLY6, 37\% for HY113 on average across two seasons (Fig. 4). Under DS, the drought tolerance cultivar HY113 showed higher IWUE than YLY6 by 17\%, and the higher water productivity of HY113 might contribute to the improved drought tolerance.

To better understand the response of WUE to DS, $\Delta$ in leaves and grain was measured. Although no significant difference between CK and DS in leaves and grain of every cultivar, YLY6 and HY113 showed significant differences in leaves and grain under both CK and DS conditions (Fig. 5).

The process of physiological changes in response to DS. No significant difference in LWP, ALTG, $\mathrm{P}_{\mathrm{n}}, \mathrm{G}_{\mathrm{s}}$, and $\mathrm{T}_{\mathrm{r}}$ occurred before DS and significant decrease were observed under DS. After 2 days of rehydration, most evaluated physiological traits could return to the normal level. However, significant decrease was observed after rehydration for 20 days compared to CK. As shown in Table 6, LWP, ALTG, $P_{n}, G_{s}$, and $T_{r}$ were reduced by $31 \%, 27 \%, 35 \%, 41 \%$ and $21 \%$, respectively. Thus, the effect of drought stress on physiological changes might be appeared at the grain filling period, and these changes might attribute to DS-triggered early senescence.

Correlation among traits for DS. The GY was positively correlated $(P<0.05)$ with SPN, FG, $P_{n}, G_{s}, L W P$ and ALTG, and negatively correlated with $\mathrm{CH}$ and IWUE $(P<0.05)$ (Table 7$)$; the FG was significantly positively correlated with SPN; the $P_{n}$ was significantly positively correlated with SPN, FG, and ALTG; the G $_{s}$ was significantly positively correlated with SPN, FG, LWP, ALTG, and $\mathrm{P}_{n}$; the ALTG was significantly positively correlated with SPN and FG; the IWUE was significantly negatively correlated with SPN, FG, $P_{n}, G_{s}$, LWP, and ALTG, significantly positively correlated with $\mathrm{CH}$; the $\mathrm{CH}$ was significantly negatively correlated with $\mathrm{FG}, \mathrm{LWP}, \mathrm{P}_{\mathrm{n}}$, and $\mathrm{G}_{\mathrm{s}}$.

As showed in the Fig. 6, the main ordination axis was significantly positively correlated with ALTG, SPN, FG, $\mathrm{G}_{\mathrm{s}}, \mathrm{P}_{\mathrm{n}}$, Yield, $\mathrm{T}_{\mathrm{r}}$ and LWP at the flowering stage, while ALTG, SPN, FG had great contributions to ordination axis. HY113-DS and YLY6-DS were negative closely related to the main ordination axis, which indicates that DS had significant effects on flag leaf photosynthetic capacity. Moreover, HY113-DS was significantly positively correlated IWUE and $\mathrm{CH}$.

\section{Discussion}

The effect of DS on rice growth at different growth periods has been widely studies. Rice can be subject to DS at any time and the responses of growth are different in different growth stages ${ }^{31,45,46}$. Some studies have showed that the most sensitive period to DS of rice development is booting stage ${ }^{31}$, and controlled irrigation and drainage at vegetative stages might be the most critical period ${ }^{47-50}$. Other studies found that the flowering stage is the most sensitive stage to water deficit ${ }^{51,52}$. The formation of rice panicle and spikelets morphogenesis are primary factors of rice yield ${ }^{53,54}$. Consistent with previous studies ${ }^{50,52,55-58}$, our results showed that DS $(-30 \mathrm{kPa})$ at the flowering stage had significant effects on GY, with the reduction of 23.2\% in YLY6 and 24.0\% in HY113, respectively (Table 2). Moreover, SPN and FG under DS conditions might have positive relation with GY based on the correlation analysis (Table 7). 


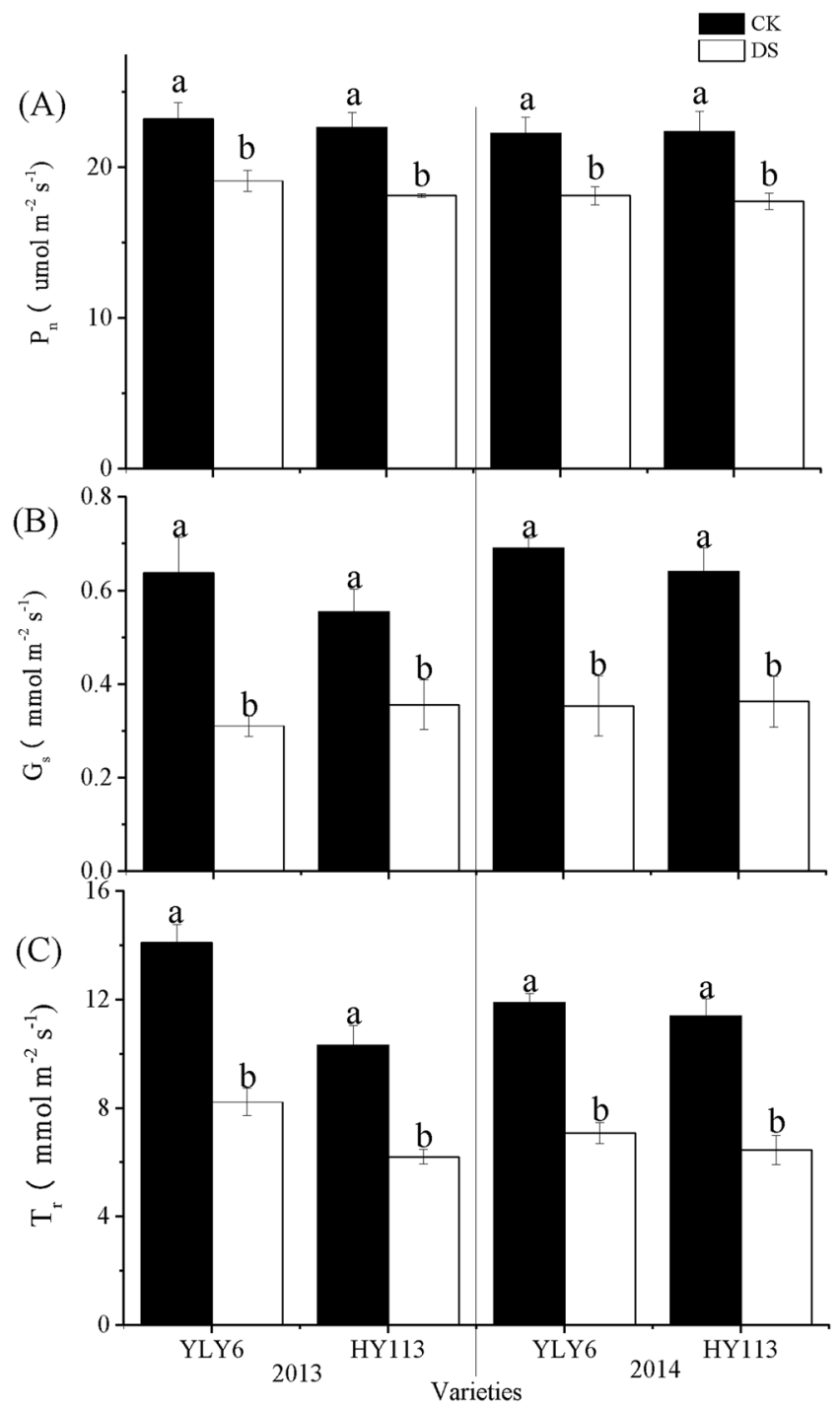

Figure 1. $P_{n}\left(\right.$ A), $G_{s}($ B $), T_{r}($ C) of two rice cultivars of YLY6 and HY113 under DS at flowering stage in 2013 and 2014. CK indicates traditional flooding cultivation and DS is drought stress at the flowering stage. The different letters in different columns under each cultivar are significantly different at the $P=0.05$ level. Vertical bars represent standard errors.

When the rice was exposed to severe DS at the flowering stage, the significant increase in spikelets sterility and GY reduction were observed ${ }^{38,51,56,59-61}$, with the decline in SPN and FG. Reduction in LWP under DS resulted in the birth defect of panicle ${ }^{62}$ and a negative correlation was found between LWP and spikelet sterility at flowering stage under $\mathrm{DS}^{38}$ and another similar indicator relative water content was conducted to demonstrate the same variation trend ${ }^{51,61,63}$. Our result showed no significant correlation between SPN and LWP (Table 7), so LWP as an indicator for determining spikelets sterility needs further validation. Moreover, ALTG displayed positive relation with SPN and FG (Table 7). Previous studies ${ }^{60,61}$ showed that spikelet fertility is sensitive to high temperature. The significant decline in ALTG under DS (Fig. 3) indicated that rice may encounter high-temperature stress for the shelter proof in greenhouse (Table 1) and anther dehiscence might contribute to the reduction in SPN and $\mathrm{FG}^{61}$. Moreover, high temperature may be a limiting factor of root and microorganism activity at the reproductive stage and accelerate leaf senescence ${ }^{64}$. In general, rice cultivation could be subject to DS accompanied with some degree of high-temperature stress. On the other hand, $\mathrm{P}_{\mathrm{n}}$ and capacity of flag leaf may be the primary source of crop yield and were susceptible to abiotic stress, especially by DS ${ }^{26,35}$. We observed that the $P_{n}, G_{s}$, and $T_{r}$ were significantly reduced (Fig. 1), and significant positive correlated with yield, in agreement with previous studies. The leaf stomatal closure resulted in limitation to carbon dioxide uptake, which reduced the source size, additionally, the leaf senescence might also explain the limitation to dry conversion to panicle during milk stage ${ }^{65,66}$. After 20 days of rehydration, YLY6 exhibited higher LWP and $P_{n}$ than HY113 (Table 6), indicating that these physiological activities during grain filling stage might contribute to the reduction in GY.

Herein, DS led to both yield losses and poor grain quality with the increase of $\mathrm{CHK}$ and $\mathrm{CH}$ degree, with no significant effect on TGW, MRR, HRR and GS (Table 4), protein content, amylose content and alkali spreading 


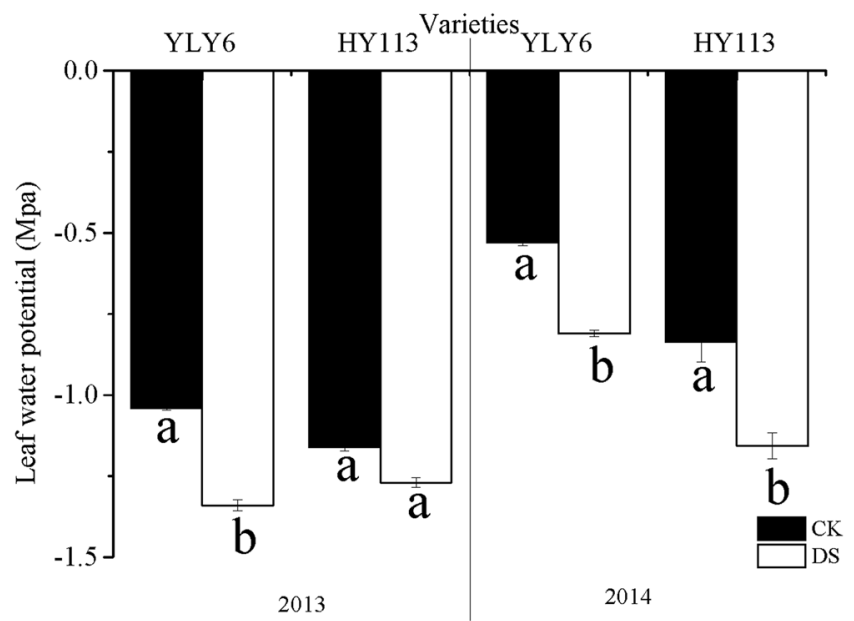

Figure 2. LWP of leaves of two rice cultivars of YLY6 and HY113 under DS at flowering stage in 2013 and 2014. CK indicates traditional flooding cultivation and DS is drought stress at the flowering stage. The different letters in different columns under each cultivar are significantly different at the $P=0.05$ level. Vertical bars represent standard errors.

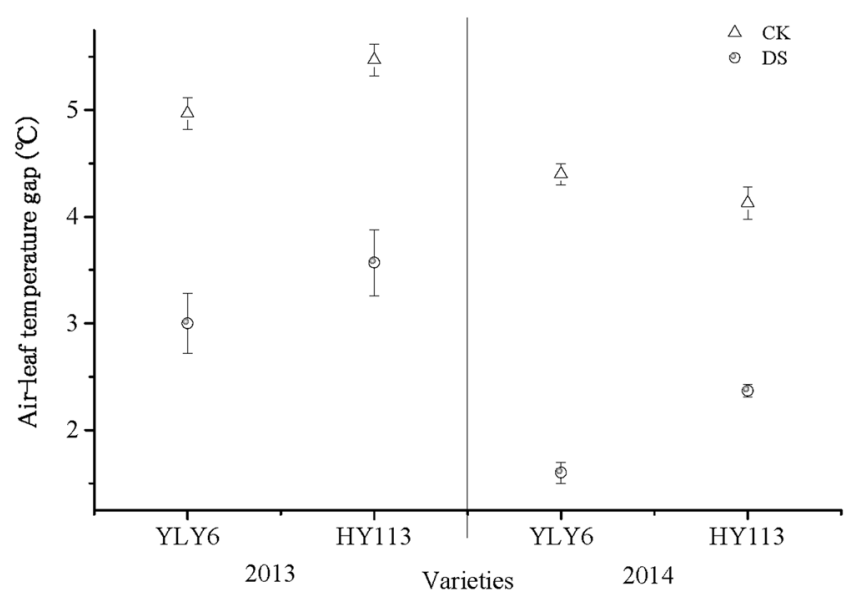

Figure 3. ALTG of two rice cultivars of YLY6 and HY113 under DS at flowering stage in 2013 and 2014. CK indicates traditional flooding cultivation and DS is drought stress at the flowering stage. The different letters in different columns under each cultivar are significantly different at the $\mathrm{P}=0.05$ level. Vertical bars represent standard errors.

value (Table 5). Under CK and DS conditions, YLY6 showed 20\% higher HRR and 27\% higher protein content than HY113, while HY113 showed 99\% higher CHK and 82\% CH (Tables 4, 5). This result suggested that YLY6 could maintain nutritional quality under DS. CHK and $\mathrm{CH}$ are mainly determined by the capacity of photosynthate from whole growth period and variation might exist in different cultivars due to genetic effects ${ }^{18}$. Our results showed that there was a negative correlation between photosynthetic and $\mathrm{CH}$ (Table 7) and significant difference was observed between YLY6 and HY113 (Table 4), DS triggered low photosynthetic capacity might also contribute to the increased $\mathrm{CH}^{67,68}$, besides higher temperature after flowering stage ${ }^{69,70}$.

Our results showed that IWUE of YLY6 and HY113 was 39\% and 37\%, respectively, and HY113 showed $17 \%$ higher IWUE than YLY6 under DS at flowering stage (Fig. 4), indicating that $\mathrm{P}_{\mathrm{n}}$ was less susceptible to reduction of $G_{s}$ than $T_{r}$ under DS. Moreover, GY of YLY6 and HY113 were reduced by $23.2 \%$ and $24.0 \%$ under DS, respectively (Table 3), and a significant negative correlation relationship was observed between GY and IWUE (Table 7; Fig. 6), the balance between higher crops water productivity and the loss of crops production caused by DS could be another concerned topic ${ }^{41}$. Our results showed a negative correlation between ALTG, LWP and IWUE (Table 7), a high leaf temperature and low LWP could be adjusted stomatal close then reduce water consumption and $\mathrm{T}_{\mathrm{r}}$ Interestingly, we observed no significant difference between $\mathrm{CK}$ and $\mathrm{DS}$ in $\Delta$, while HY113 showed higher IWUE and water productivity but lower $\Delta$ than YLY6 (Fig. 4). The stable $\Delta$ shows negative relation with WUE in plants $^{28,29,32,71}$. The inconsistence among these previous studies might be probably due to the sampling location, timing (growth stage) and extent of DS, lead to variation in outcomes ${ }^{32,71}$. 


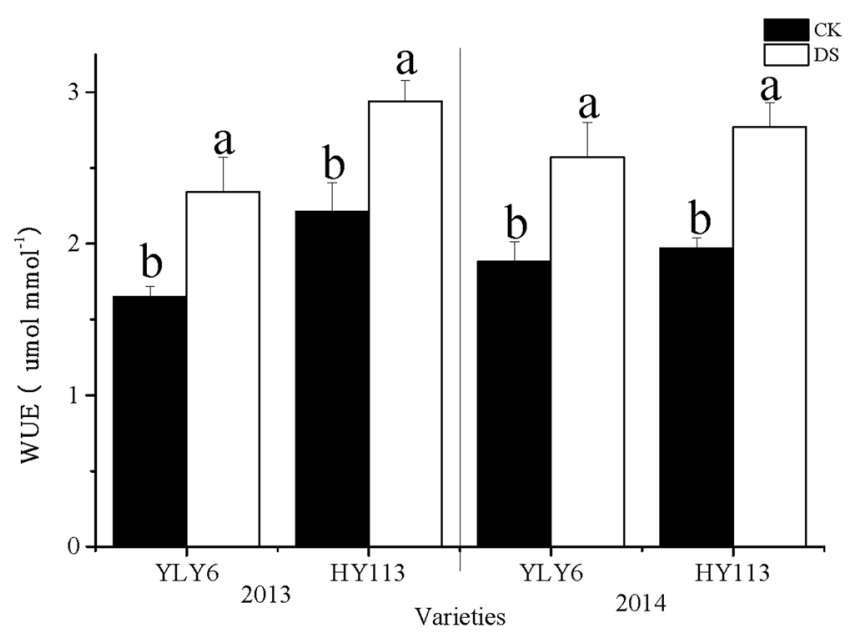

Figure 4. The IWUE of two rice cultivars of YLY6 and HY113 under DS at flowering stage in 2013 and 2014. CK indicates traditional flooding cultivation and DS is drought stress at the flowering stage. The different letters in different columns under each cultivar are significantly different at the $\mathrm{P}=0.05$ level. Vertical bars represent standard errors.

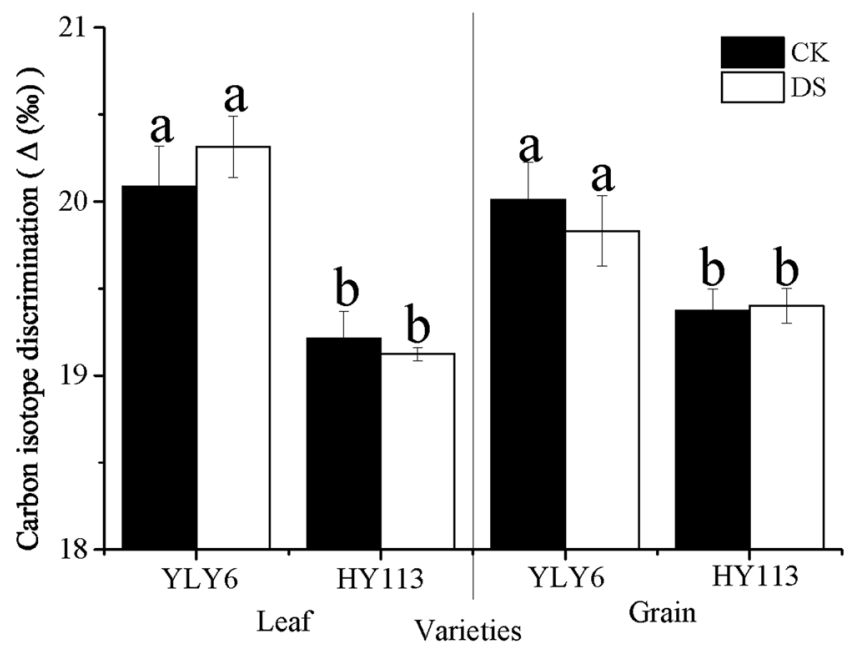

Figure 5. The $\Delta$ of two rice cultivars of YLY6 and HY113 under DS at flowering stage in 2014. CK indicates traditional flooding cultivation and DS is drought stress at the flowering stage. The different letters in different columns under each cultivar are significantly different at the $\mathrm{P}=0.05$ level. Vertical bars represent standard errors.

\section{Conclusion}

DS at flowering stage could significantly reduce GY, with decline in SPN and FG. YLY6 showed significant reduction in physiological activities in response to DS, with better recovery capability after DS than HY113. Our results suggest that it is improper to evaluate drought resistance ability only by the performance in response to drought at flowering stage, because the selected susceptible varieties may have better recovery capability after DS than the selected resistant varieties. Thus, better recovery capability is important to keep relatively high grain production under DS conditions.

\section{Materials and Methods}

Site description. Field experiments were conducted in 2013 and 2014 under a rainproof shelter at Huazhong Agricultural University, Hubei Province, China $\left(30^{\circ} 28^{\prime} \mathrm{N}, 114^{\circ} 21^{\prime} \mathrm{E}\right)$ during rice growing season (May to October). The soil type was a clay loam $(\mathrm{pH}=5.7)$ with $18 \mathrm{~g} \mathrm{~kg}^{-1}$ organic matter, $1.4 \mathrm{~g} \mathrm{~kg}^{-1}$ total N, $0.85 \mathrm{mg} \mathrm{kg}^{-1}$ total $\mathrm{P}$, and $118.8 \mathrm{mg} \mathrm{kg}^{-1}$ total $\mathrm{K}$. The field capacity soil moisture content was $28.5 \%$ and bulk density of the soil was $1.2 \mathrm{~g} \mathrm{~cm}^{-3}$. To minimize water infiltration between plots, plastic film was applied on the plot bunds and the plastic film was installed under soil surface with a depth of $15 \mathrm{~cm}$. To prevent water from CK to DS, the main plots were separated with cement concrete $(20 \mathrm{~cm}$ width). The average data of air temperature during the rice-growing across two study years recorded by temperature and humidity monitoring equipment (TPJ-20, 


\begin{tabular}{|c|c|c|c|c|c|c|c|c|c|c|c|c|c|c|c|c|c|c|c|c|c|}
\hline \multirow[b]{2}{*}{ Varieties } & \multirow[b]{2}{*}{ Treatment } & \multicolumn{4}{|c|}{ LWP (Mpa) } & \multicolumn{4}{|c|}{ ALTG $\left({ }^{\circ} \mathrm{C}\right)$} & \multicolumn{4}{|c|}{$P_{n}\left(\right.$ umol.m $\left.m^{-2} \cdot s^{-1}\right)$} & \multicolumn{4}{|c|}{$\mathrm{G}_{\mathrm{s}}\left(\mathrm{mmol} \cdot \mathrm{m}^{-2} \cdot \mathrm{s}^{-1}\right)$} & \multicolumn{4}{|c|}{$\mathrm{T}_{\mathrm{r}}\left(\mathrm{mmol} \cdot \mathrm{m}^{-2} \cdot \mathrm{s}^{-1}\right)$} \\
\hline & & BDS & DS & ARD2 & ARD 20 & BDS & DS & ARD2 & ARD 20 & BDS & DS & ARD2 & ARD 20 & BDS & DS & ARD2 & ARD 20 & BDS & DS & ARD2 & ARD 20 \\
\hline \multirow{2}{*}{ YLY6 } & CK & $-0.58 \mathrm{a}$ & $-0.53 \mathrm{a}$ & $-0.49 a$ & $-0.62 \mathrm{a}$ & $2.57 \mathrm{a}$ & $4.40 \mathrm{a}$ & $2.37 \mathrm{a}$ & $0.90 \mathrm{a}$ & $22.7 \mathrm{a}$ & $22.3 \mathrm{a}$ & $22.8 \mathrm{a}$ & $15.5 \mathrm{a}$ & $0.62 \mathrm{a}$ & $0.69 \mathrm{a}$ & $0.55 \mathrm{a}$ & $0.18 \mathrm{a}$ & $8.42 \mathrm{a}$ & $11.9 \mathrm{a}$ & $9.15 \mathrm{a}$ & $4.64 \mathrm{a}$ \\
\hline & DS & $-0.63 a$ & $-0.81 \mathrm{~b}$ & $-0.54 \mathrm{a}$ & $-0.84 \mathrm{~b}$ & $2.53 \mathrm{a}$ & $1.60 \mathrm{~b}$ & $1.60 \mathrm{~b}$ & $0.50 \mathrm{~b}$ & $22.6 \mathrm{a}$ & $18.1 \mathrm{~b}$ & $21.4 \mathrm{a}$ & $11.9 \mathrm{~b}$ & $0.62 \mathrm{a}$ & $0.35 \mathrm{~b}$ & $0.57 \mathrm{a}$ & $0.12 \mathrm{~b}$ & $8.30 \mathrm{a}$ & $7.07 \mathrm{~b}$ & $8.09 \mathrm{~b}$ & $3.40 \mathrm{~b}$ \\
\hline \multirow{2}{*}{ HY113 } & CK & $-095 a$ & $0.84 \mathrm{a}$ & $-0.77 \mathrm{a}$ & $-0.81 \mathrm{a}$ & $4.20 \mathrm{a}$ & $4.13 \mathrm{a}$ & $3.23 \mathrm{a}$ & $1.27 \mathrm{a}$ & $21.5 \mathrm{a}$ & $22.4 \mathrm{a}$ & $23.4 \mathrm{a}$ & $15.6 \mathrm{a}$ & $0.55 \mathrm{a}$ & $0.64 \mathrm{a}$ & $0.65 a$ & $0.33 \mathrm{a}$ & $6.77 \mathrm{a}$ & $11.4 \mathrm{a}$ & $9.64 a$ & $6.22 \mathrm{a}$ \\
\hline & DS & $-0.99 a$ & $-1.16 \mathrm{~b}$ & $-0.66 \mathrm{a}$ & $-1.02 b$ & $4.07 \mathrm{a}$ & $2.37 \mathrm{~b}$ & $1.67 \mathrm{~b}$ & $1.15 \mathrm{a}$ & $21.3 \mathrm{a}$ & $17.8 \mathrm{~b}$ & $21.5 \mathrm{a}$ & $8.42 \mathrm{~b}$ & $0.53 \mathrm{a}$ & $0.36 \mathrm{~b}$ & $0.55 b$ & $0.17 \mathrm{~b}$ & $6.37 \mathrm{a}$ & $6.44 \mathrm{~b}$ & $6.50 \mathrm{~b}$ & $5.26 \mathrm{a}$ \\
\hline
\end{tabular}

Table 6. The dynamic of LWP, ALTG and photosynthetic traits of YLY6 and HY113 at flowering stage in 2014. Before drought stress, BDS; Drought stress, DS; After 2 days of rehydration, ARD 2; After 20 days of rehydration, ARD 20; Photosynthetic, $\mathrm{P}_{\mathrm{n}}$; Stomatal conductance, $\mathrm{G}_{\mathrm{s}}$; Ttranspiration rate, $\mathrm{T}_{\mathrm{r}}$. Different letters indicate statistical significance according to $\operatorname{LSD}(P=0.05)$.

\begin{tabular}{|l|l|l|l|l|l|l|l|l|l|}
\hline & GY & SPN & FG & CH & LWP & ALTG & $\mathbf{P}_{\mathbf{n}}$ & G $_{\mathbf{s}}$ & IWUE \\
\hline SPN & $0.717^{* *}$ & & & & & & & & \\
\hline FG & $0.787^{* *}$ & $0.855^{* *}$ & & & & & & & \\
\hline CH & $-0.581^{*}$ & -0.322 & -0.409 & & & & & & \\
\hline LWP & $0.567^{*}$ & 0.252 & 0.370 & $-0.561^{*}$ & & & & & \\
\hline ALTG & $0.599^{*}$ & $0.678^{* *}$ & $0.770^{* *}$ & -0.235 & -0.078 & & & & \\
\hline $\mathrm{P}_{\mathrm{n}}$ & $0.729^{* *}$ & $0.777^{* *}$ & $0.737^{* *}$ & $-0.625^{* *}$ & 0.297 & $0.661^{* *}$ & & & \\
\hline $\mathrm{G}_{\mathrm{s}}$ & $0.785^{* *}$ & $0.698^{* *}$ & $0.734^{* *}$ & $-0.535^{*}$ & $0.614^{*}$ & $0.497^{*}$ & $0.733^{* *}$ & & \\
\hline IWUE & $-0.722^{* *}$ & $-0.618^{*}$ & $-0.623^{*}$ & $0.832^{* *}$ & $-0.487^{*}$ & $-0.467^{*}$ & $-0.755^{* *}$ & $-0.747^{* *}$ & \\
\hline$\Delta$ & 0.225 & -0.175 & 0.078 & $-0.620^{* *}$ & 0.324 & -0.007 & 0.192 & 0.126 & -0.314 \\
\hline
\end{tabular}

Table 7. Correlations among the physiological traits of YLY6 and HY113 under drought stress at flowering stage across two years. *Significant at the 0.05 probability level. **Significant at the 0.01 probability level.

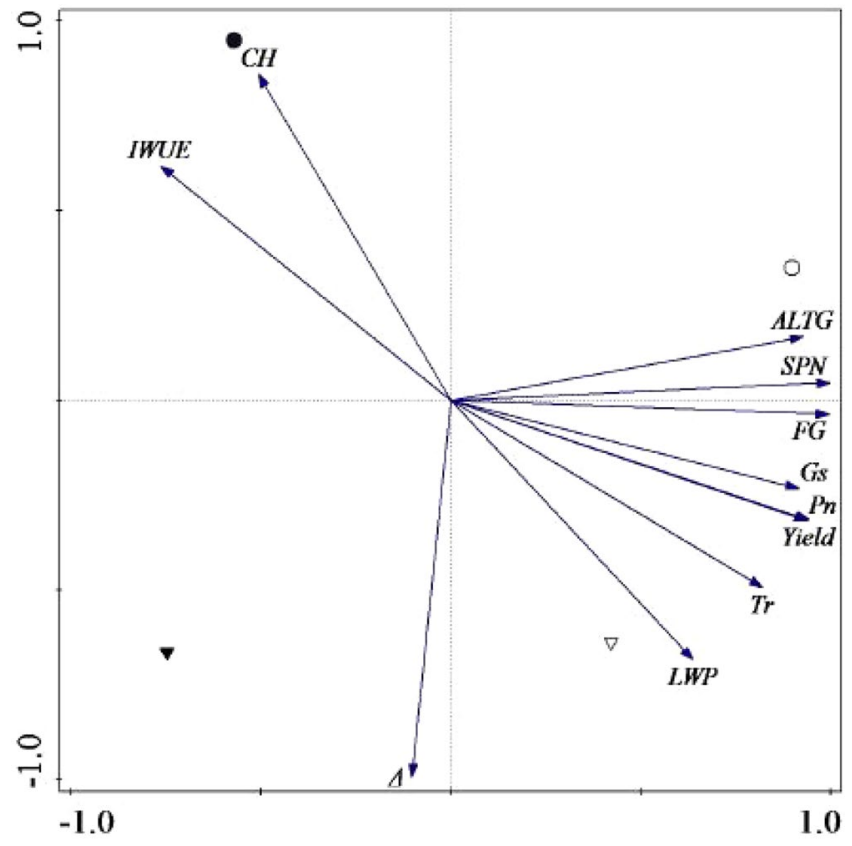

Figure 6. Principal component analysis of target traits. Grain yield, GY; Spikelets per panicle, SPN; Filled grains, FG; Chalkiness, CH; Leaf water potential, LWP; Air-leave temperature gap, ALTG; Net photosynthetic, $\mathrm{P}_{\mathrm{n}}$; Stomatal conductance, $\mathrm{G}_{\mathrm{s}}$; Instantaneous water use efficiency, IWUE; Carbon isotope discrimination, $\Delta$; HY113-drought stress $(\bullet)$; HY113-traditional flooding $(\bigcirc)$; YLY6-drought stress $(\boldsymbol{\nabla})$; YLY6- traditional flooding $(\nabla)$.

Tuopu Instruments Ltd, Zhejiang, China), installed close to the experimental site, and precipitation was excluded for the rainproof shelter and the open-ended rainproof shelter ensures that rice growth was not affected by high temperature. 
Experiment design. Two water management treatments were compared in a split-plot with four replicates with a plot size of $3 \mathrm{~m} \times 6 \mathrm{~m}$ in 2013 and 2014. The main plots were two water treatments, including CK and DS at the flowering stage. The sub-plots were two rice cultivars, "super" hybrid rice of YLY6 and drought tolerance rice of HY113. YLY6 is a two-line hybrid rice variety with characteristics of high yield and high quality and higher drought tolerance and bred by Lixiahe Regional Research of Agricultural Science (Jiangsu province, China), widely cultivated in Hubei Province. HY113 is an indica three-line hybrid upland rice has characteristics of drought resistance and capacity of water saving and bred by Shanghai Agricultural Biological Gene Center (Shanghai province, China). The two rice cultivars showed similar growth periods, which can ensure both genotypes flower at the same time.

To better understand the dynamic change of rice before and after DS, we chose four-time nodes; before DS (BDS), DS, after 2 days of rehydration (ARD 2), after 20 days of rehydration (ARD 20) in 2014 as a supplementary trial. The CK treatment plots were puddled and continuously flooded with $1-3 \mathrm{~cm}$ water level during the 15 days after transplanting. Thereafter, the water level was gradually increased to $5-10 \mathrm{~cm}$ at the full rice crop development until 2 weeks before harvest. While the DS treatment plots were imposed DS by withholding water at the flowering stage during the 60 days after transplanting, and soil water potential was monitored by soil tensiometer (JX-2, Tuopu Instruments Ltd., Zhejiang, China) with three in each plot for maintaining the soil water potential at $-30 \pm 5 \mathrm{kPa}$ level at $15 \mathrm{~cm}$ depth.

Twenty-day-old seedlings were transplanted at a hill spacing of $13.3 \mathrm{~cm} \times 30 \mathrm{~cm}$ with two seedlings per hill on 10 May 2013 and 1 May 2014. N fertilizer was applied at the rate of $180 \mathrm{~kg} \mathrm{~N}^{-h^{-1}} ; 50 \%$ as basal, $20 \%$ at the tillering stage and $30 \%$ at the panicle initiation stage, respectively. Potassium fertilizer and phosphate fertilizer were applied as basal fertilizer at the rate of $100.5 \mathrm{~kg} \mathrm{~K}_{2} \mathrm{O} \mathrm{ha}^{-1}$ and $100.5 \mathrm{~kg} \mathrm{P}_{2} \mathrm{O}_{5}$ ha ${ }^{-1}$, respectively. Agro-chemicals and hand weeded practices were applied to diseases, pests and weed management during the growing season to avoid yield loss.

The recorded parameters are described below.

Leaf gas exchange measurements and $\Delta$. Leaf gas-exchange measurements of rice were carried out under both CK and DS conditions with LI-6400XT portable photosynthesis measurement system (Li-Cor, Lincoln, NE, USA). The net $\mathrm{P}_{\mathrm{n}}\left(\mu \mathrm{mol} \mathrm{CO} \mathrm{Cm}^{-2} \mathrm{~s}^{-1}\right), \mathrm{G}_{\mathrm{s}}\left(\mathrm{mol} \mathrm{m}^{-2} \mathrm{~s}^{-1}\right), \mathrm{T}_{\mathrm{r}},\left(\mu \mathrm{mol} \mathrm{m}^{-2} \mathrm{~s}^{-1}\right)$ of the flag leaves (fully expanded functional leaves) were determined at the flowering stage during 9:00-11:00 without cloud days when the photosynthetic active radiation (PAR) was greater or equal to $1000 \mathrm{umol} \mathrm{m}^{-2} \mathrm{~s}^{-1}$ in the morning which could ensure that maximum value could be detected and relative humidity ranging between $45 \%-55 \%$, a leaf temperature of $30^{\circ} \mathrm{C}$. Nine flag leaves of rice were measured for each treatment. IWUE was calculated as the ratio of $P_{n}$ to $\mathrm{G}_{\mathrm{s}}$.

$\Delta$ was analyzed in rice leaves at flowering stage and in rice grains at maturity. Rice leaves samples were dried at $105^{\circ} \mathrm{C}$ for 1 hour then at $80^{\circ} \mathrm{C}$ until a stable weight and rice seeds were dried at $25^{\circ} \mathrm{C}$ for 3 months and then grind to milled rice. All the dried samples were ground using ball mill MM401 (Retsch, Germany) and sifted through a $0.5 \mathrm{~mm}$ screen. Stable Isotope ratio mass spectrometer (Thermo, Delta V Advantage, Agawam, USA) was applied to determine the carbon isotope discrimination in Crop Physiology and Production Center (CPPC) in Huazhong Agricultural University, Wuhan.

LWP and Air-leaf temperature gap. At the flowering stage, rice fully expanded functional leaves (flag leaves) were sampled and cut into small pieces and mixed immediately with less than 20 s at 13:00-15:00 in a sunny day and the time chose to sample leaves was determined based on a preliminary study when the lowest LWP was achieved, and LWP were determined using a water potential analyzer (WP4C, Decagon Devices Inc., USA).

Meanwhile, the air temperature (T1) above canopy was automatically recorded by a data logger (TPJ-20, Tuopu Instruments Ltd, Zhejiang, China) which was installed above the top of rice canopy in the center of the plot, and the flag leaf (fully expanded functional leaves) temperature was measured using the UT300A infra-red thermometer (TPJ-20, Tuopu Instruments Ltd, Zhejiang, China) during 13:00 to 15:00 the detector ranged with $1 \mathrm{~cm}$ the leaf surface and temperature of flag leaves (T2) were measured with a portable infrared thermometer UT300A (TPJ-20, Tuopu Instruments Ltd, Zhejiang, China), on sunny days. The time chosen to measure leaf temperature was determined based on a preliminary study (data not shown) when the stable air temperature was achieved. The ALTG was calculated by air temperature and leaf temperature difference, as described: $\mathrm{ALTG}=\mathrm{T} 1-\mathrm{T} 2$.

Harvesting and grain quality measurements. At maturity stage, GY was obtained from a 5- $\mathrm{m}^{2}$ area in each plot except board line, and the standard grain moisture content of $14 \%$ was applied to yield calculation. What is more, 8 hills were taken from each plot according to the average number of EPs, and each hill was processed separately. Panicles number was recorded from every hill, each panicle was hand-threshed and the unfilled spikelets were separated from filled spikelets through a blower. The EP, TGW, FG were calculated. FG was calculated as the described formula: $100 \times$ filled spikelet number/total spikelet number, and the SPN as follow: GY per square meter $/(\mathrm{TGW} \times \mathrm{EP} \times \mathrm{FG})$.

After measuring the GY components, grains harvested from each plot were retained and dried at $40^{\circ} \mathrm{C}$ in a dryer to keep the water content at $13 \%$ before quality measurements. A $125 \mathrm{~g}$ sample of rice grains were dehulled by dehusker, milled by a polisher, then separated into broken and unbroken grains, and weighted respectively. Estimate the BRR, HRR, and MRR were expressed as percentages of total (125 g) rice grains. The flatbed scanner WinRHIZO (Microtek, Shanghai, China), SC-E software (Hangzhou, Wanshen Detection Technology Co., Ltd., Hangzhou, China) and professional image analysis software Image J (National Institutes of Health- NIH, USA) were applied to analysis the GS, $\mathrm{CH}$ and $\mathrm{CHK}$ using milled grains according to Rice Quality Measurement 
Standards (Ministry of Agriculture, PR China, 1988). The amylose content and alkali spreading value were measured using head grains according to Rice Quality Measurement Standards (Ministry of Agriculture, PR China, 1988 , and the protein in milled grains was determined using an infrared grain quality analyzer (TM-1241, Foss Tecator AB, Denmark).

Statistical analysis. Data were analyzed by analysis of variance (ANOVA) (SAS Institute, 1999) and means were compared based on the least significant difference (LSD) test at the 5\% probability level. The correlation among growth characteristics of these two cultivars was measured by using the CORR model in SAS. Principal components analysis (PCA) was performed in CANOCO 5.0 (Microcomputer Power Ithaca, USA; Braak and Smilauer, 2012).

\section{References}

1. Uga, Y. et al. Control of root system architecture by Deeper Rooting 1 increases rice yield under drought conditions. Nat. Genet. 45, 1097-1102 (2013).

2. Zhu, J. K. Abiotic stress signaling and responses in plants. Cell. 167, 313-324 (2016).

3. Bouman, B. A. M. \& Toung, T. P. Field water management to save water and increase its productivity in irrigated lowland rice. Agric. Water Mange. 49, 11-30 (2001).

4. Bouman, B. A. M. A conceptual framework for the improvement of crop water productivity at different spatial scales. Agric. Syst. 93, 43-60 (2007).

5. Ashraf, M. Inducing drought tolerance in plants: Recent advances. Biotechnology Advances. 28, 169-183 (2010).

6. Venuprasad, R., Lafitte, H. R. \& Atlin, G. N. Response to direct selection for grain yield under drought stress in rice. Crop Sci. 47, 285-293 (2009)

7. Li, G. et al. The sequences of 1504 mutants in the model rice variety Kitaake facilitate rapid functional genomic studies. Plant Cell. 29, 1218-1231 (2017).

8. National Bureau of Statistics of China, China Statistical Yearbook 2015. Beijing: China Statistics Press, pp. 244, http://www.stats.gov. $\mathrm{cn} / \mathrm{tjsj} / \mathrm{ndsj} / 2015 /$ indexeh.htm. (In English) (2015).

9. Liu, C. L., Zhang, Q., Singh, V. P. \& Cui, Y. Copula-based evaluations of drought variations in Guangdong. South China. Nat. Hazards. 59, 1533-1546 (2011).

10. Belder, P. et al. Effect of water-saving irrigation on rice yield and water use in typical lowland conditions in Asia. Agric. Water Manage. 65, 193-210 (2004).

11. Kamoshita, A., Babu, R. C., Bhupathi, N. M. \& Fukai, S. Phenotypic and genotypic analysis of drought-resistance traits for development of rice cultivars adapted to rainfed environments. Field Crops Res. 109, 1-23 (2008).

12. Palanog, A. D. et al. Grain yield QTLs with consistent-effect under reproductive-stage drought stress in rice. Field Crops Res. 161, 46-54 (2014).

13. Gana, A. S. Screening and resistance of tradition and improved cultivars of rice to drought stress at Badeggi, Niger state, Nigeria. Agric. Biol. North Am. 2, 1027-1031 (2011).

14. Kumar, A. et al. Breeding high-yielding drought tolerance rice: Genetic variations and conventional and molecular approaches. J. Exp. Bot. 65, 6265-6278 (2014).

15. Babu, R. C. et al. Genetic analysis of drought resistance in rice by molecular markers: Association between secondary traits and field performance. Crop Sci. 43, 1457-1469 (2003).

16. Han, Y. et al. Genes coding for starch branching enzymes are major contributors to starch viscosity characteristics in waxy rice (Oryza sativa L.). Plant Sci. 166, 357-364 (2004).

17. Zhang, Z. C., Zhang, S. F., Yang, J. C. \& Zhang, J. H. Yield, grain quality and water use efficiency of rice under non-flooded mulching cultivation. Field Crops Res. 108, 71-81 (2008).

18. Shi, C. H., Wu, J. G., Lou, X. B., Zhu, J. \& Wu, P. Genetic analysis of transparency and chalkiness area at different filling stage of rice (Oryza sativa L.). Field Crops Res. 76, 1-9 (2002).

19. Singh, N., Sodhi, N. S., Kaur, M. \& Saxena, S. K. Physico-chemical, morphological, thermal, cooking and textural properties of chalky and translucent rice kernels. Food Chem. 82, 433-439 (2003).

20. Liu, Q. H. et al. Effects of high air temperature on rice grain quality and yield under field condition. Agron. J. 105, 446-454 (2013).

21. Calingacion, M. et al. Diversity of global rice markets and the science required for consumer-targeted rice breeding. Plos One 9 , e85106 (2014).

22. Cuevas, R. P., Pede, V. O., MCKinley, J., Velarde, O. \& Demont, M. Rice Grain Quality and Consumer Preferences: A Case Study of Two Rural Towns in the Philippines. Plos One 11, e0150345 (2016).

23. Zu, X. F. et al. A new method for evaluating the drought tolerance of upland rice cultivars. The Crop. J. 5, 488-498 (2017).

24. Medrano, H. et al. From leaf to whole-plant water use efficiency (WUE) in complex canopies: Limitations of leaf WUE as a selection target. The Crop J. 3, 220-228 (2015).

25. Yoichiro, K., Midori, O. \& Keisuke, K. Yield potential and water use efficiency of aerobic rice (Oryza sativa L.) in Japan. Field Crops Res. 113, 328-334 (2009).

26. Lauteri, M., Haworth, M., Serraj, R., Monteverdi, M. C. \& Centritto, M. Photosynthetic diffusional constraints affect yield in drought stressed rice cultivars during flowering. Plos One 9, e109054 (2014).

27. Farquhar, G. D. \& Richards, R. A. Isotopic composition of plant carbon correlates with water use efficiency of wheat genotypes. Aust. J. Plant Physiol. 11, 539-552 (1984).

28. Dingkuhn, M., Farquhar, G. D., De Datta, S. K. \& Toole, T. C. Discrimination of ${ }^{13} \mathrm{C}$ among upland rice having different water use efficiency. Aust. J. Agri. Res. 42, 1123-1131 (1991).

29. Farquhar, G. D., O’Leary, M. H. \& Berry, J. A. On the relationship between carbon isotope discrimination and the intercellular carbon dioxide concentration in leaves. Aust. J. Plant Physiol. 9, 121-137 (1982).

30. Blum, A. Effective use of water (EUW) and not water-use efficiency (WUE) is the target of crop yield improvement under drought stress. Field Crops Res. 112, 119-123 (2009).

31. Shao, G. C. et al. Effects of controlled irrigation and drainage on growth, grain yield and water use in paddy rice. Eur. J. Agron. 53, 1-9 (2014)

32. Xu, Y. B. et al. Leaf-level water use efficiency determined by carbon isotope discrimination in rice seedlings: genetic variation associated with population structure and QTL mapping. Theor. Appl. Genet. 118, 1065-1081 (2009).

33. Centritto, M., Lauteri, M., Monteverdi, M. C. \& Serraj, R. Leaf gas exchange, carbon isotope discrimination, and grain yield in contrasting rice genotypes subjected to water deficits during the reproductive stage. J. Exp. Bot. 60, 2325-2339 (2009).

34. Gu, J., Yin, X., Stomph, T. J., Wang, H. \& Struik, P. C. Physiological basis of genetic variation in leaf photosynthesis among rice (Oryza sativa L.) introgression lines under drought and well-watered conditions. J. Exp. Bot. 63, 5137-5153 (2012).

35. Madana, M. R. A. et al. Coordinated regulation of photosynthesis in rice increases yield and tolerance to environmental stress. Nat. Commun. 5, 5302 (2014). 
36. Serraj, R. et al. Drought resistant rice: physiological framework for an integrated research strategy. In: Serraj, R., Bennett, J., Hardy, B. eds Drought frontiers in rice: crop improvement for increased rainfed production. Singapore: World Scientific Publishing, Los Ban `os, Philippines: International Rice Research Institute. 139-170 (2008).

37. Wang, L. et al. The relationships between carbon isotope discrimination and photosynthesis and rice yield under shading. Int. J. Plant Prod. 10, 551-564 (2016).

38. Jongdee, B., Fukai, S. \& Cooper, M. Leaf water potential and osmotic adjustment as physiological traits to improve drought tolerance in rice. Field Crops Res. 76, 153-163 (2002).

39. Lawlor, D. W. \& Cornic, G. Photosynthetic carbon assimilation and associated metabolism in relation to water deficits in higher plants. Plant Cell Environ. 25, 275-94 (2002).

40. Xu, W. G., Hu, L. \& Gai, J. Y. A study on heat tolerance of wheat cultivars. Acta. Agric. Boreali-Sin. 14, 1-5 (1999).

41. Peng, S. H., XU, J. Z., Ding, J. L. \& Li, D. X. Leaf-air temperature difference of rice and water deficit diagnose under water saving irrigation. J. Hydraul. Eng. 15, 1503-1506 (2006)

42. Zhang, W., Jin, F. F. \& Jin, A. Turner. Increasing autumn drought over southern China associated with ENSO regime shift. Geophys. Res. Lett. 41, 4020-4026 (2014).

43. Zhang, W., Jin, F. F., Zhao, J. X., Qi, L. \& Ren, H. L. The possible influence of a non-conventional El Nino on the severe autumn drought of 2009 in Southwest China. J. Clim. 26, 8392-8405 (2013).

44. Verulkar, S. B. et al. Breeding resilient and productive genotypes adapted to drought-prone rainfed ecosystem of India. Field Crops Res. 117, 197-208 (2010).

45. Boonjung, H. \& Fukai, S. Effects of soil water deficit at different growth stages on rice growth and yield under upland conditions. 2. Phenology, biomass production and yield. Field Crops Res. 48, 47-55 (1996).

46. Mostajeran, A. \& Rahimi-Eichi, R. Effects of drought stress on growth and yield of rice (Oryza sativa L.) Cultivars and accumulation of proline and soluble sugars in sheath and blades of their different ages leaves. American-Eurasian J. Agric. \& Environ. Sci. 5, 264-272 (2009).

47. Fukai, S., Pantuwan, G., Jongdee, B. \& Cooper, M. Screening for drought resistance in rainfed lowland rice. Field Crop Res. 64, 61-74 (1999).

48. Inthavong, T., Tsubo, M. \& Fukai, S. A water balance model for characterization of length of growing period and water stress development for rainfed lowland rice. Field Crops Res. 121, 291-301 (2011).

49. Ji, K. X. et al. Drought-responsive mechanisms in rice genotypes with contrasting drought tolerance during reproductive stage. Field Crops Res. 169, 336-344 (2012).

50. Trijatmiko, K. R. et al. Meta-analysis of quantitative trait loci for grain yield and component traits under reproductive-stage drought stress in an upland rice population. Mol. Breed. 34, 283-295 (2014).

51. Liu, J. X. et al. Genetic variation in the sensitivity of anther dehiscence to drought stress in rice. Field Crops Res. 97, 87-100 (2006).

52. Zinolabedin, T. S., Hemmatollah, P., Seyed, A. M. M. S. \& Hamidreza, B. Study of water stress effects in different growth stages on yield and yield components of different rice (Oryza sativa L.) Cultivars. Pak. J. Biol. Sci. 11, 1303-1309 (2008).

53. Gravois, K. A. \& Helms, R. S. Path analysis of rice yield and yield components as affected by seeding rate. Agron. J. 841, 1-4 (1992).

54. Chang, S. Q., Chang, T. G., Song, Q. F., Zhu, X. G. \& Deng, Q. Y. Photosynthetic and agronomic traits of an elite hybrid rice Y-LiangYou 900 with a record-high yield. Field Crops Res. 187, 49-57 (2016).

55. Pantuwan, G., Fukai, S., Cooper, M., Rajatasereekul, S. \& O’Toole, J. C. Yield response of rice (Oryza sativa L.) genotypes to drought under rainfed lowlands.1. Grain yield and yield components. Field Crops Res. 73, 153-168 (2001).

56. Pantuwan, G., Fukai, S., Cooper, M., Rajatasereekul, S. \& O’Toole, J. C. Yield response of rice (Oryza sativa L.) genotypes to drought under rainfed lowlands. 2. Selection of drought resistant genotypes. Field Crops Res. 73, 169-180 (2002).

57. Sasaki, K. et al. Fine mapping of a quantitative trait locus for spikelet number per panicle in a new plant type rice and evaluation of a near-isogenic line for grain productivity. J. Exp. Bot. 68, 2693-2702 (2017).

58. Okada, S., Sasaki, M. \& Yamasaki, M. A novel rice QTL qOPW11 associated with panicle weight affects panicle and plant architecture. Rice. 11, 53 (2018).

59. Kamoshita, A., Rofriguez, R., Yamauchi, A. \& Wade, L. J. Genotypic variation in response of rainfed lowland to prolonged drought and re-watering. Plant Prod. Sci. 7, 406-420 (2004).

60. Praba, M. L., Cairns, J. E., Babu, R. C. \& Lafitte, H. R. Identification of physiological traits underlying cultivar differences in drought tolerance in rice and wheat. J. Agron. Crop Sci. 195, 30-46 (2009).

61. Rang, Z. W., Jagadish, S. V. K., Zhou, Q. M., Craufurd, P. Q. \& Heuer, S. Effect of high temperature and water stress on pollen germination and spikelet fertility in rice. Environ. Exp. Bot. 70, 58-65 (2011).

62. O’Toole, J. C. \& Namuco, O. S. Role of panicle exsertion in water stress induced sterility. Crop Sci. 23, 1093-1097 (1983).

63. Lafitte, R. Relationship between leaf relative water content during reproductive stage water deficit and grain formation in rice. Field Crops Res. 76, 165-174 (2002).

64. Funaba, M., Ishibashi, Y., Molla, A. H., Iwanami, K. \& Iwaya-Inoue, M. Influence of low/high temperature on water status in developing and maturing rice grains. Plant Pro. Sci. 9, 347-354 (2006).

65. Li, M., Shi, Q., Zeng, M., Pan, X. \& Tan, X. Effects of sink-source characters of hybrid rice main season on growth and development of ratooning rice. Chin. Agric. Sci. Bulletin. 25, 175-181 (2009).

66. Jiang, Y. et al. Non-target effects of Bt transgenes on grain yield and related traits of an elite restorer rice line in response to nitrogen and potassium applications. Field Crops Res. 169, 39-48 (2014).

67. Liu, L., Yuan, L., Wang, Z., Xu, G. \& Cheng, Y. Preliminary studies on the physiological reason and countermeasure of lodging in non-flooded rice. Chin. J. Rice Sci. 16, 225-230 (2002).

68. Qin, J., Hu, F., Zhang, B., Wei, Z. \& Li, H. Role of straw mulching in non-continuously flooded rice cultivation. Agric. Water Manage. 83, 252-260 (2006).

69. Yang, J. C. \& Zhang, J. H. Grain filling of cereals under soil drying. New Phytol. 169, 223-236 (2006).

70. Cheng, J. L. et al. Effects of short-term high temperature on grain quality and starch granules of rice (Oryza sativa L.) at post-anthesis stage. Protoplasma. 254, 935-943 (2017)

71. Knight, J. D., Livingston, N. J. \& Kessel, C. V. Carbon isotope discrimination and water-use efficiency of six crops grown under wet and dryland conditions. Plant Cell Environ. 17, 173-179 (1994)

\section{Acknowledgements}

This study was supported by National Natural Science Foundation of China (31801291) and the State Key Special Program (2017YFD0301400). We thank Mingli Cai, Huazhong Agricultural University, for technical assistance.

\section{Author Contributions}

Ping Li and Cougui Cao conceived the experiments. Xiaolong Yang, Benfu Wang and Liang Chen conducted the experiments and collected the data. Xiaolong Yang analyzed the data and wrote the manuscript. All authors revised the manuscript. 


\section{Additional Information}

Competing Interests: The authors declare no competing interests.

Publisher's note: Springer Nature remains neutral with regard to jurisdictional claims in published maps and institutional affiliations.

(c) (i) Open Access This article is licensed under a Creative Commons Attribution 4.0 International License, which permits use, sharing, adaptation, distribution and reproduction in any medium or format, as long as you give appropriate credit to the original author(s) and the source, provide a link to the Creative Commons license, and indicate if changes were made. The images or other third party material in this article are included in the article's Creative Commons license, unless indicated otherwise in a credit line to the material. If material is not included in the article's Creative Commons license and your intended use is not permitted by statutory regulation or exceeds the permitted use, you will need to obtain permission directly from the copyright holder. To view a copy of this license, visit http://creativecommons.org/licenses/by/4.0/.

(C) The Author(s) 2019 